\title{
STUDENTS' AND STUDENT TEACHERS' SENSE OF BELONGING TO SCIENCE: WHAT DO WE KNOW SO FAR?
}

\author{
Markus Sebastian Feser \\ University of Hamburg, Germany
}

Forming a sense of belonging to others is a fundamental need of humans as social beings (Baumeister \& Leary, 1995). Meeting this fundamental need crucially influences individuals' intrinsic motivation (Ryan \& Deci, 2000) and identity development (Wenger, 1999). Given this, a growing number of studies have investigated the extent to which university students' success and wellbeing in science education is related to their sense of belonging to science. This research has brought greater clarity to university students' development in science education; however, numerous aspects of university students' sense of belonging to science remain understudied. In particular, there has been insufficient research on how sense of belonging to science might moderate or influence initial science teacher education. Therefore, this editorial aims to provide an overview of the major research findings that address students' and student teachers' sense of belonging to science and to inspire future research in science (teacher) education.

\section{What Do We Know about University Students' Sense of Belonging to Science?}

To date, higher education research has mostly focused on students' sense of belonging to their university. Among other findings, this research has revealed that students' university belonging positively influences their academic satisfaction (Fischer, 2007), academic engagement (Gillen-O'Neel, 2021), and level of academic achievement (Strayhorn, 2006). However, this global perspective on sense of belonging in higher education leaves unexplored the challenges of science education (e.g., the high dropout rates in academic science programs and the underrepresentation of minority students; Good et al., 2012; Lewis \& Hodges, 2015). Moreover, prior research has shown that the challenges associated with science education relate more to the characteristics of the culture of science (Lemke, 2001) - for example, the image of science as a "tough discipline" - than to those of a particular university. Consequently, since 2010, a growing number of studies have examined students' sense of belonging to science, instead of their university belonging.

An individual's sense of belonging to science relates to their social affiliation with and within the natural sciences. It is a complex multidimensional construct that manifests through the following five feelings and needs (Feser, 2020; Good et al., 2012; Kuchynka et al., 2019):

1. Feeling connected to people who are involved and engaged in the natural sciences.

2. Feeling acknowledged by people who are involved and engaged in the natural sciences.

3. Strong emotional wellbeing around people who are involved and engaged in the natural sciences.

4. The desire to be noticed by people who are involved and engaged in the natural sciences.

5. Feeling a special interpersonal trust towards people who are involved and engaged in the natural sciences. 
Recent studies suggest that university students' sense of belonging to science substantially correlates with their science-related mindset beliefs, their interest in sciences and their experience of achievement in the natural sciences (e.g., Lytle \& Shin, 2020; Muenks et al., 2020; Rattan et al., 2018). Sense of belonging to science results from socialization through and within the natural sciences and is biographically shaped (Shin et al., 2016, p. 411). For students that belong to an underrepresented or marginalized group (e.g., women, LGBTQ students, students of color), such socialization may include experiences of discrimination or exclusion (Bilimoria \& Stewart, 2009; Johnson, 2012). This may explain why these students tend to have a lower sense of belonging to science than non-marginalized groups (Cech \& Rothwell, 2018; Rainey et al., 2019).

For university students, socialization through and within the natural sciences is often interlinked with academic learning experiences. However, this socialization also occurs in non-academic contexts, such as experiences within secondary science education or leisure activities related to science. Therefore, although sense of belonging to science and university belonging are associated and show close interdependencies, it is possible to differentiate between these constructs both theoretically and empirically (Feser, 2020; Findley-Van Nostrand \& Pollenz, 2017).

\section{What Do We Know about Student Teachers' Sense of Belonging to Science?}

Very recently, sense of belonging to science has emerged as a topic within research on science teacher education. For example, based on earlier research, Chung-Parsons and Bailey (2019) argued that science teachers should possess a distinct sense of belonging to science, "if they are to model and foster ... [their] students' own science identity development" (p. 40). Unfortunately, student science teachers often feel labeled as second-class science students, especially within science faculties that award social status based predominantly on science-related competencies rather than teaching-related competencies (Oevermann, 2010, p. 378). This, in turn, negatively influences student teachers' sense of belonging to science.

Nevertheless, so far, only a handful of empirical studies have examined the role of sense of belonging to science in science teacher education. A qualitative study conducted by Danielsson et al. (2016) found that a lack of a sense of belonging to science is associated with a stronger sense of distance and alienation toward the natural sciences among student science teachers. Similarly, Fejes and Köpsén (2014) reported that in-service science teachers with a limited sense of belonging to science struggle to identify themselves as academic representatives of the natural sciences. Finally, a quantitative study conducted by Feser (2020) revealed that student teachers who undertake more extensive studies in science have a significantly greater sense of belonging to science than those who undertake less extensive studies, and that student teachers' sense of belonging to science moderately correlates with their academic satisfaction, their interest in science, and the extent to which they attach personal value to the natural sciences.

\section{Implications for Future Science (Teacher) Education Research}

As shown by the above overview, university students' sense of belonging to science is critical in shaping their development in science education. However, only in the last decade has research begun noticeably examining students' sense of belonging to science. Therefore, a variety of research gaps remain in this area, especially in relation to student teachers' sense of belonging to science. Among these, the following research gaps appear to be both the most pressing and potentially fruitful for further investigation:

First, most existing studies on students' sense of belonging to science are quantitative and rely on Likert-scaled questionnaires. While this approach is well suited for surveying a large number of students across universities to obtain a broad understanding of the bigger picture, more qualitative and case-based studies are needed, especially considering the biographically shaped nature of students' sense of belonging to science. Such qualitative studies would supply more profound insights into the individual development of university students.

Second, existing studies on students' sense of belonging to science have holistically considered all natural sciences, rather than comparing students by scientific discipline. Therefore, whether and to what extent students' sense of belonging to science differs depending on the scientific discipline they are studying remains unknown. A detailed analysis that accounts for students' scientific disciplines (e.g., biology, chemistry, physics, or earth sciences) is desirable.

Third, the extent to which existing findings on students' sense of belonging to science can be generalized across geographic regions is unclear. Most of the studies on students' sense of belonging to science have origi- 
nated in North America, while the few studies that address (pre-service) science teachers' sense of belonging to science were conducted in Western Europe. Further research on students' sense of belonging to science needs to be conducted in a range of geographical regions to provide evidence on possible regional or national differences.

Fourth, even though the research on student teachers' sense of belonging to science is sparse, it is reasonable to assume that the findings on students' sense of belonging to science in general are transferrable to student teachers. However, this supposition requires empirical verification. Indeed, considering that student science teachers are socialized not only in the natural sciences but also in the educational sciences, there may be some distinctions in their sense of belonging to science compared to non-teaching bound science students. Future research that compares student teachers and students not studying to become teachers in terms of their sense of belonging to science could offer insight into this supposition.

Finally, there is a lack of research examining the extent to which (student) teachers' sense of belonging to science might moderate or influence the quality of their science teaching. The few empirical studies on student teachers' sense of belonging to science suggest that such connections may be possible. Therefore, investigating the possible connection between (student) teachers' sense of belonging to science and their teaching practice may be a promising area for future research.

\section{References}

Baumeister, R. F., \& Leary, M. R. (1995). The need to belong: Desire for interpersonal attachments as a fundamental human motivation. Psychological Bulletin, 117(3), 497-529. https://doi.org/10.1037/0033-2909.117.3.497

Bilimoria, D., \& Stewart, A. J. (2009). “Don't ask, don't tell”: The academic climate for lesbian, gay, bisexual, and transgender faculty in science and engineering. NWSA Journal 21(2), 85-103. https://www.muse.jhu.edu/article/316151.

Cech, E. A., \& Rothwell, W. R. (2018). LGBTQ inequality in engineering education. Journal of Engineering Education, 107(4), 583-610. https://doi.org/10.1002/jee.20239

Chung-Parsons, R., \& Bailey, J. M. (2019). The hierarchical (not fluid) nature of preservice secondary science teachers' perceptions of their science teacher identity. Teaching and Teacher Education, 78, 39-48. https://doi.org/10.1016/j.tate.2018.11.007

Danielsson, A. T., Andersson, K., Gullberg, A., Hussénius, A., \& Scantlebury, K. (2016). "In biology class we would just sit indoors...": Experiences of insideness and outsideness in the places student teachers associate with science. Cultural Studies of Science Education, 11(4), 1115-1134. https://doi.org/10.1007/s11422-015-9702-8

Fejes, A., \& Köpsén, S. (2014). Vocational teachers' identity formation through boundary crossing. Journal of Education and Work, 27(3), 265-283. https://doi.org/10.1080/13639080.2012.742181

Feser, M. S. (2020). Sense of belonging to science-Entwicklung eines Erhebungsinstruments für Lehramtsstudierende [Development of an instrument measuring student teachers' sense of belonging to science]. Progress in Science Education (PriSE), 3(2), 10-21. https://doi.org/10.25321/prise.2020.968

Findley-Van Nostrand, D., \& Pollenz, R. S. (2017). Evaluating psychosocial mechanisms underlying STEM persistence in undergraduates: Evidence of impact from a six-day pre-college engagement STEM academy program. CBE-Life Sciences Education, 16(2), article 36. https://doi.org/10.1187/cbe.16-10-0294

Fischer, M. J. (2007). Settling into campus life: Differences by race/ethnicity in college involvement and outcomes. The Journal of Higher Education, 78(2), 125-156. https://doi.org/10.1353/jhe.2007.0009

Gillen-O'Neel, C. (2021). Sense of belonging and student engagement: A daily study of first- and continuing-generation college students. Research in Higher Education, 62, 45-71. https://doi.org/10.1007/s11162-019-09570-y

Good, C., Rattan, A., \& Dweck, C. S. (2012). Why do women opt out? Sense of belonging and women's representation in mathematics. Journal of Personality and Social Psychology, 102(4), 700-717. https://doi.org/10.1037/a0026659

Johnson, D. R. (2012). Campus racial climate perceptions and overall sense of belonging among racially diverse women in STEM majors. Journal of College Student Development, 53(2), 336-346. https://doi.org/10.1353/csd.2012.0028

Kuchynka, S., Findley-Van Nostrand, D., \& Pollenz, R. S. (2019). Evaluating psychosocial mechanisms underlying STEM persistence in undergraduates: Scalability and longitudinal analysis of three cohorts from a six-day pre-college engagement STEM academy program. CBE-Life Sciences Education, 18(3), Article 41. https://doi.org/10.1187/cbe.19-01-0028

Lemke, J. L. (2001). Articulating communities: Sociocultural perspectives on science education. Journal of Research in Science Teaching, 38(3), 296-316. https://doi.org/10.1002/1098-2736(200103)38:3\%3C296::AID-TEA1007\%3E3.0.CO;2-R

Lewis, K. L., \& Hodges, S. D. (2015). Expanding the concept of belonging in academic domains: Development and validation of the Ability Uncertainty Scale. Learning and Individual Differences, 37, 197-202. https://doi.org/10.1016/j.lindif.2014.12.002

Lytle, A., \& Shin, J. E. (2020). Incremental beliefs, STEM efficacy and STEM interest among first-year undergraduate students. Journal of Science Education and Technology, 29, 272-281. https://doi.org/10.1007/s10956-020-09813-z

Muenks, K., Canning, E. A., LaCosse, J., Green, D. J., Zirkel, S., Garcia, J. A., \& Murphy, M. C. (2020). Does my professor think my ability can change? Students' perceptions of their STEM professors' mindset beliefs predict their psychological vulnerability, engagement, and performance in class. Journal of Experimental Psychology: General, 149(11), 2119-2144. https://doi. org/10.1037/xge0000763 
ISSN 1648-3898/Print/ STUDENTS' AND STUDENT TEACHERS' SENSE GF BELONGING TI SCIENCE: WHAT DQ WE

Oevermann, U. (2010). Der Gegenbegriff zur Gesellschaft ist nicht Natur sondern Kultur [The counter concept to society is not nature but culture]. In F. Herrschaft \& K. Lichtblau (Eds.), Soziologie in Frankfurt. Eine Zwischenbilanz [Sociology in Frankfurt. An interim report] (pp. 369-406). VS Verlag für Sozialwissenschaften.

Rainey, K., Dancy, M., Mickelson, R., Stearns, E., \& Moller, S. (2019). A descriptive study of race and gender differences in how instructional style and perceived professor care influence decisions to major in STEM. International Journal of STEM Education, 6(1), 6. https://doi.org/10.1186/s40594-019-0159-2

Rattan, A., Savani, K., Komarraju, M., Morrison, M. M., Boggs, C., \& Ambady, N. (2018). Meta-lay theories of scientific potential drive underrepresented students' sense of belonging to science, technology, engineering, and mathematics (STEM). Journal of Personality and Social Psychology, 115(1), 54-75. https://doi.org/10.1037/pspi0000130

Ryan, R. M., \& Deci, E. L. (2000). Self-determination theory and the facilitation of intrinsic motivation, social development, and well-being. American Psychologist, 55(1), 68-78. https://doi.org/10.1037/0003-066X.55.1.68

Shin, J. E. L., Levy, S. R., \& London, B. (2016). Effects of role model exposure on STEM and non-STEM student engagement: Role model. Journal of Applied Social Psychology, 46(7), 410-427. https://doi.org/10.1111/jasp.12371

Strayhorn, T. L. (2006). Factors influencing the academic achievement of first-generation college students. Journal of Student Affairs Research and Practice, 43(4), 82-111. https://doi.org/10.2202/1949-6605.1724

Wenger, E. (1999). Communities of practice: Learning, meaning, and identity. Cambridge University Press.

\section{Markus Sebastian Feser}

PhD, Research Associate in Science Education, Department of Social Sciences, Mathematics and Natural Sciences Education (EW5), Faculty of Education, University of Hamburg, Von-Melle-Park 8, 20146 Hamburg, Germany.

E-mail: Markus.Sebastian.Feser@uni-hamburg.de Website: http://www.markusfeser.de/en/ ORCID: https://orcid.org/0000-0001-8503-0951 